\title{
Eremiolirion, a new genus of southern African Tecophilaeaceae, and taxonomic notes on Cyanella alba
}

\author{
J.C. MANNING*, F. FOREST** and C.A. MANNHEIMER***
}

Keywords: biogeography, Cyanella alba L.f., Cyanella L., Eremiolirion amboense (Schinz) J.C.Manning \& C.Mannheimer, Eremiolirion J.C.Manning \& F.Forest, gen. nov., Namibia, South Africa, Tecophilaeaceae

\section{ABSTRACT}

\begin{abstract}
The generic affiliation of Cyanella amboensis Schinz has been uncertain since the species was excluded from the genus Cyanella L. in 1991. The species has two leaves, a divaricately branching inflorescence, ebracteolate pedicels, and actinomorphic flowers with monomorphic anthers. It is endemic to the western parts of central and northern Namibia. Other species of Cyanella have several leaves, racemose inflorescences, bracteolate pedicels, zygomorphic flowers with dimorphic anthers, and are endemic or near-endemic to the winter rainfall region in southwestern South Africa and southern Namibia. These differences are consistent with the recognition of the species as a distinct genus within the family. Phylogenetic analysis of plastid DNA sequences indicates that $C$. amboensis Schinz is sister to the other species of Cyanella, a relationship that also supports its independent generic status. The monotypic genus Eremiolirion is accordingly erected to accommodate the species. Minor differences in flower colour and vegetative morphology in Cyanella alba L.f. are shown to correlate with the three disjunct groups of populations in which the species occurs, and these populations are recognized at the level of subspecies.
\end{abstract}

Tecophilaeaceae are a small family of geophytic perennials well circumscribed by their cormous rootstock, poricidal anthers and semi-inferior ovary (Simpson \& Rudall 1998). The flowers of all species are attractive, brightly coloured and often fragrant (Manning et al. 2002). The family comprises 24 species, currently distributed among eight small genera, three of which are monotypic. The genus Odontostomum Torr. (1 sp.) is endemic to California, Conanthera Ruíz \& Pav. (5 spp.), Tecophilaea Bertero ex Colla (2 spp.) and Zephyra D.Don (1 sp.) are restricted to Chile, and the remaining four, Cyanastrum Oliv. ( $3 \mathrm{spp}$.), Cyanella L. (7 or 8 spp.), Kabuyea Brummitt (1 sp.) and Walleria J.Kirk (3 spp.), occur in sub-Saharan Africa (Simpson \& Rudall 1998). An analysis of plastid sequence data for the $r b c \mathrm{~L}$ gene and the $t r n \mathrm{~L}-\mathrm{F}$ region for all genera and most species (18), places the three Chilean genera as sister to the Californian-African clade and retrieves all genera as monophyletic (Forest \& Manning 2005 in prep.).

The African genera have been thoroughly monographed (Carter 1962; Scott 1991; Brummitt et al. 1998). Among them, Cyanastrum and Kabuyea are found only in the tropics, Walleria is widely dispersed through subtropical Africa, and Cyanella is almost restricted to the winter rainfall region of South Africa in the extreme southwest of the continent. A single species of Cyanella, C. amboensis Schinz is found further north, in central Namibia. This species is morphologically anomalous among the rest of the species of Cyanella and was excluded from the genus by Scott (1991) pending a reap-

\footnotetext{
* Compton Herbarium, South African National Biodiversity Institute, Private Bag X7, 7735 Claremont, Cape Town.

* Leslie Hill Molecular Systematics Laboratory, South African National Biodiversity Institute, Private Bag X7, 7735 Claremont, Cape Town \& Department of Botany, University of Cape Town, Private Bag. 7701 Rondebosch, Cape Town.

*** National Herbarium of Namibia, National Botanical Research Institute, Private Bag 13184, Windhoek.

MS. received: 2005-04-05.
}

praisal of its relationships within the family. A label appended to the specimen Bean, Vlok \& Viviers 1824 (BOL) indicates that at the time she had considered that the species might be best transferred to the Chilean genus Conanthera, with which it shares a branched inflorescence and symmetrical anthers, but the similarity is not actually that close. Conanthera has numerous leaves and a zygomorphic, blue to purple perianth, in contrast to the bifoliate condition and actinomorphic, white perianth of C. amboensis. Currently, therefore, the species is of uncertain generic affinity. Molecular evidence places $C$. amboensis as sister to a monophyletic clade comprising the remaining species in the genus (six of the seven remaining species are included in this study). This topology offers two options for resolving the generic position of $C$. amboensis: the species can either be incorporated within an expanded circumscription of the genus Cyanella; or a new genus should be erected to accommodate it. The morphological differences between Cyanella s. str. and C. amboensis are substantial, including leaf number, inflorescence structure, floral symmetry, and arrangement of the androecium. Genera in Tecophilaeaceae as currently circumscribed are homogeneous assemblages of closely related species in which floral symmetry in particular plays a defining role. Including C. amboensis within Cyanella would not only enlarge the circumscription of the genus to the extent that it is no longer morphologically coherent but would render it uniquely heterogeneous in comparison to the other genera in the family.

Cyanella s. str. is circumscribed on the basis of its tunicated corm, several to numerous leaves, zygomorphic flowers with dimorphic anthers, and bracteolate pedicels. All of the species are endemic to or centred in the winter rainfall region of southern Africa. Cyanella amboensis, in contrast, has just two leaves, the flowers are truly actinomorphic with monomorphic anthers, the pedicels are ebracteolate, and the species is distributed in summer rainfall Namibia. On the basis of these several 


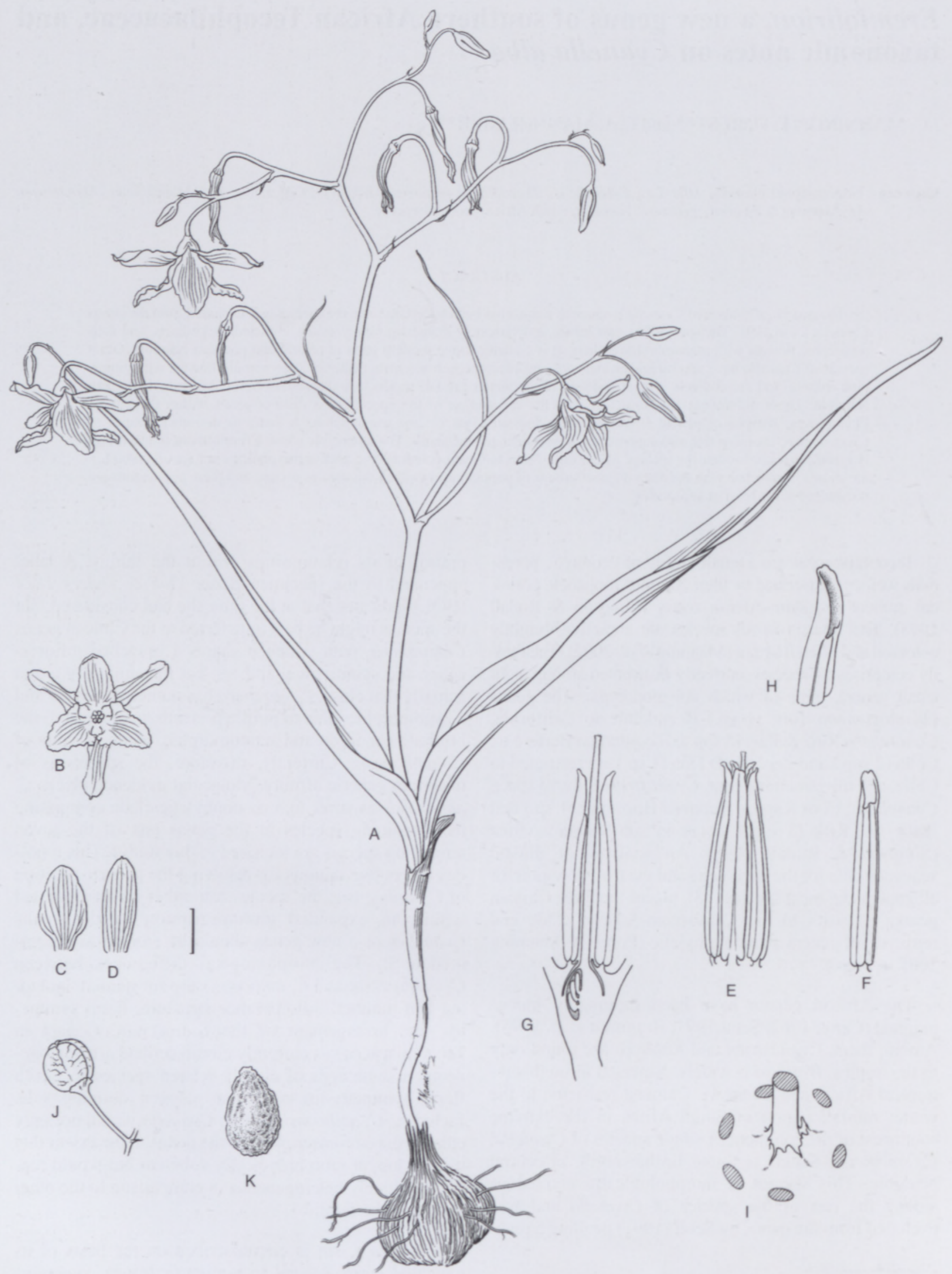

FIGURE 1.-Eremiolirion amboense, Mannheimer 2510 (NBG). A, whole plant; B, flower, front view; C, inner tepal; D, outer tepal; E, androecium; F, single anther, adaxial surface; G, half flower detail; H, tip of anther; I, detail of mouth of floral tube showing corona; J, capsule; $\mathrm{K}$, seed. Scale bar: A-D, J, $10 \mathrm{~mm}$; E-G, $2.5 \mathrm{~mm} ; \mathrm{H}, 3.75 \mathrm{~mm}$; I, $1 \mathrm{~mm} ; \mathrm{K}, 2 \mathrm{~mm}$. Artist: J.C. Manning. 
morphological and ecological differences, the species is most appropriately accommodated in a separate genus closely allied to but distinct from Cyanella $s$. str., for which we propose the name Eremiolirion.

\section{Eremiolirion J.C.Manning \& F.Forest, gen. nov.}

Species unica, a speciebus Cyanellae duobusfoliis, pedicellis sine bracteolis, floribus actinomorphis, antheris monomorphis distinguenda.

TYPE.-Eremiolirion amboense (Schinz) J.C.Manning \& C.A. Mannheimer (= Cyanella amboensis Schinz).

Deciduous geophytể with deep-seated, subglobose to oblate tunicated corm, tunics decaying into firm-leathery, coarsely netted fibres extending into neck. Cataphyll pale membranous. Leaves 2, basal, narrowly lanceolate, canaliculate with prominent midrib abaxially, leathery. Inflorescence divaricately branching, paniculate cyme; bracts subtending branches and pedicels only; pedicels cernuous at tip, elongating slightly in fruit and straightening. Flowers actinomorphic, nodding, campanulate, white flushed abaxially with pink or maroon; tepals 6 in two whorls, connate below into short tube with minute, fringed corona present at mouth of tube; tepals dimorphic, outer oblong, inner pandurate. Stamens 6, monomorphic, symmetrical, attached to perianth near mouth of tube; anthers basifixed, erect and connivent around style, narrowly lanceolate, dehiscing by oblong apical pores. Ovary half inferior, trilocular; ovules several per locule; style terete, erect, straight, slightly tapering; stigma minute. Capsules ovoid to globose. Seeds ellipsoid-pyriform, blackish brown, testa surface rugose.

Distribution: a single species in central and northwestern Namibia.

Etymology: the name is a compound of the Greek eremios (desert or wilderness) and lirion (white lily).

Eremiolirion amboense (Schinz) J.C.Manning \& C.A.Mannheimer, comb. nov.

Cyanella amboensis Schinz in Bulletin de l'Herbier Boissier, sér. 2 2: 943 (1902). Type: South West Africa [Namibia], Amboland [Ovamboland], Ondonga, [Ondongwa], Rautenen 344 (Z, holo.!).

Plants (60-)100-250 mm high. Corms deep-seated, $30 \mathrm{~mm}$ diam; tunics decaying into firm-leathery, coarsely netted fibres extending into neck, $10-60 \mathrm{~mm}$ long, pale whitish brown. Cataphyll extending to ground level, pale membranous. Leaves 2 , basal, suberect, narrowly lanceolate, (10-)15-25 x (8-)10-20 mm, attenuate, canaliculate with prominent midrib abaxially, leathery. Inflorescence divaricately branching, paniculate cyme, (1-)3-7-branched, up to 30-flowered; bracts subtending branches and pedicels only, lowermost linear-attenuate, conduplicate, up to $80 \times 2 \mathrm{~mm}$, becoming progressively shorter, uppermost lanceolate, attenuate to aristate, $3 \times 1$ $\mathrm{mm}$; pedicels cernuous at tip, 15-25 mm long, elongating slightly in fruit and straightening, ultimately $20-40$ mm long. Flowers nodding, campanulate, white flushed abaxially with pink or maroon at base of outer tepals, fragrant; perianth tube $\pm 4 \times 5 \mathrm{~mm}$ with fringed corona, 0.5-1.0 mm high, at mouth of tube and forming collar extending over ovary to surround base of style; outer

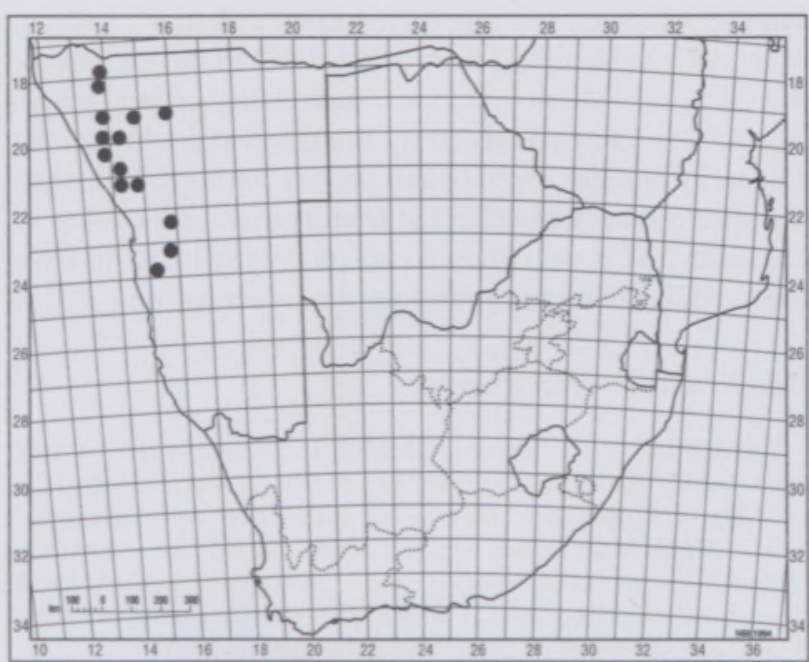

FIGURE 2.-Distribution of Eremiolirion amboense.

tepals spreading from base, oblong, obtuse, margins revolute, 15-20 × 5-7 mm; inner tepals at first suberect but spreading in upper half, pandurate, shortly clawed, claw $\pm 2 \mathrm{~mm}$ long, blade ovate, $13-18 \times 7-10 \mathrm{~mm}$, margins crisped, apex slightly cucullate. Stamens attached to perianth near mouth of tube; filaments terete, $\pm 0.25 \mathrm{~mm}$ long, anthers narrowly lanceolate, 9-10 mm long; yellow, dehiscing by oblong apical pore, $1.5 \mathrm{~mm}$ long. Ovary half inferior; ovules \pm 6 per locule; style extending $\pm 1 \mathrm{~mm}$ beyond anthers, white, 10-12 mm long. Capsules ovoid to globose, $10-12 \times 8-12 \mathrm{~mm}$. Seeds ellipsoid-pyriform, 4.0-4.5 × 3.0-3.5 mm, blackish brown; testa surface rugose. Figure 1.

Distribution and ecology: locally common through the higher-lying parts of west-central and northwestern Namibia, occurring along the better watered, western edge of the escarpment from west of Mariental in the south to Kaokoland in the north (Figure 2). The species typically occurs in colonies, often numbering many individuals, in sandy loam or heavy clay soils, especially in stony or gravelly situations. The flowers close up at night around 21:00, re-opening in the morning around 09:00. They are fragrant during the day, with a jasmine-like fragrance at first but later smelling of stale urine, and are visited by bees and the occasional moth (Ward, Ward \& Ward 10518). The dormant corms sprout only in response to good summer rains, flowering mainly in February and March, sometimes as early as mid-January and rarely into early April, depending on the timing of the rains. In drier years when rainfall is below the average annual of $\pm 175 \mathrm{~mm}$, the species flowers poorly or not at all. The extent of flowering is also dependant on the amount of rain received. In addition, if the rains are patchy, migratory herds of springbok and zebra move into the areas very quickly and consume both the leaves and the inflorescences eagerly. The corms comprise part of the traditional diet of the San around Etosha (Giess, Volk \& Bleissner 6039).

History: the species was first collected by Rev. Martti Rautanen of the Finnish Missionary Society, who arrived in Cape Town in late December 1868 with his colleagues on their way to establish mission stations in Ovamboland in northern South West Africa, now Namibia (Gunn \& Codd 1981). Rautanen's interest in natural history was stimulated by the visit of the German botanist, Dr Hans Schinz, 
who spent seven months of his botanical tour of South West Africa [Namibia] from 1884-1887 in the vicinity of the Olukondo Mission Station where Rautanen was based. Schinz was greatly assisted by Rautanen and returned the favour by naming several plant species for him. Since then the species has been collected from numerous localities to the south and is well known enough among locals to have received the charming sobriquet, desert snowdrop.

\section{Additional material examined}

NAMIBIA. - 1713 (Swartbooisdrif): W of Ombazu, (-DD), 9 April 1973 (fruiting), W. Giess 12658 (WIND), W. Giess \& Van der Walt 12658 (WIND). 1813 (Ohopoho): near Ohopoho, (-BB), May 1961 (fruiting), G. Gibson 201 (WIND); Onduvi, Orumana, (-BB), 20 February 1969 (fruiting), B.J. Grobbelaar 82 (WIND). 1913 (Sesfontein): Kunene, Barab River, (-DB), 23 March 2001, A. Burke 1020 (WIND). 1914 (Kamanjab): $40 \mathrm{~km}$ E of Otjovasandu, (-BB), 3 May 1973 (fruiting), Le Roux 527 (PRE, WIND); Etendeka Mountain Camp, 1058 m, (-DD), 28 February 2004, C. Mannheimer 2510 (NBG, WIND). 1915 (Okaukuejo): Etosha, Adamax, (-BB), 16 January 1974, Le Roux 597 (PRE, WIND); Etosha Pan, \pm 11 miles NW of Okaukuejo, (-BB), 27 March 1963, W. Giess, O.H. Volk \& B. Bleissner 6039 (WIND); \pm 1 km E of Leeubron, (-BB), 15 February 1985 , S. Brown \& H. Kolberg 302 (PRE, WIND). 2013 (Unjab Mouth): Farm Driefontein OU. 716, (-BD), 25 March 1977, M. Müller \& W. Giess 381 (WIND). 2014 (Welwitschia): S side of watershed Ugab/Huab Rivers NW of Brandberg, (-CA), 10 April 1989, C.J. Ward, J.D. Ward \& M.C. Ward 10518 (PRE, WIND); Twyfelfontein area, at gate to Petrified Forest, (-CB), 17 February 1978, P. Craven 633 (WIND); between Gaiais-Doros road and Huab River \pm in line with Krone, $(-C C), 31$ March 1984 (fruiting), $P$. Craven 1504 (WIND); Doros, Rhinowasser, (-CD), 22 March 1984, J. Knowles 6 (PRE, WIND). 2114 (Uis): 16 miles W of Brandberg, West Mine on road to Uis, (-AA), 20 March 1967, W. Giess 9715 (PRE, WIND); Omaruru, S of Brandberg, (-BA), 20 March 1967, W. Giess 9708 (PRE, WIND). 2315 (Rostock): Swakopmund, W of Kuiseb Canyon, (-BD), 10 February 1966, W. Giess 9131 (PRE, WIND); W of Kuiseb, (-BD), 27 January 1972, W. Giess \& H. Hübsch 11612 (PRE, WIND); between Solitaire and Rostock in deep red sand, (-BD), 19 April 1987, P.A. Bean, Vlok \& Viviers 1824 (BOL); 30 miles W of Solitaire near Kuiseb Canyon, (-BD), 3 April 1973, M.F. Thompson 1569 (NBG, PRE); Farm Greylingshof SW 107, (-BD), 16 February 1963 (fruiting), W. Giess, O.H. Volk \& B. Bleissner 5158 (PRE, WIND); 10 miles W of Klein Tinkas along road to Salem, (-CD), 17 March 1967, W. Giess 9642 (WIND).

\section{Uncertain locality}

NAMIBIA.-Goabis, 25 December 1908, Dinter 664 (SAM); Grootfontein District, 19 January 1912, Dinter s.n. (SAM).

Key to the southern African genera of Tecophilaeaceae

1a Corm lacking a tunic; leaves cauline, grading into floral bracts, flowers thus axillary; seeds deeply lobed or papillate with tuft of hairs on each lobe or papilla ........Walleria

lb Corm with fibrous tunic; leaves basal, sharply differentiated from bracts, flowers thus racemose or cymose; seeds rugose:

2a Leaves (3-)5-8; inflorescence racemose, sometimes sparsely branched; pedicels bearing a dorsal bracteole in upper half; flowers zygomorphic; stamens dimorphic, in two groups (either $3+3$ or $5+1)$.

$2 \mathrm{~b}$ Leaves 2 ; inflorescence a divaricate panicle; pedicels without bracteoles; flowers actinomorphic; stamens monomorphic, connivent

\section{Cyanella alba $L . f$.}

The genus Cyanella comprises seven species of deciduous geophytes concentrated in the winter rainfall region at the southwestern tip of southern Africa (Scott 1991). Among them, Cyanella alba is easily the most distinctive, distinguished from all others by its linear-filiform leaves and contracted inflorescence axis. In this species the indi-

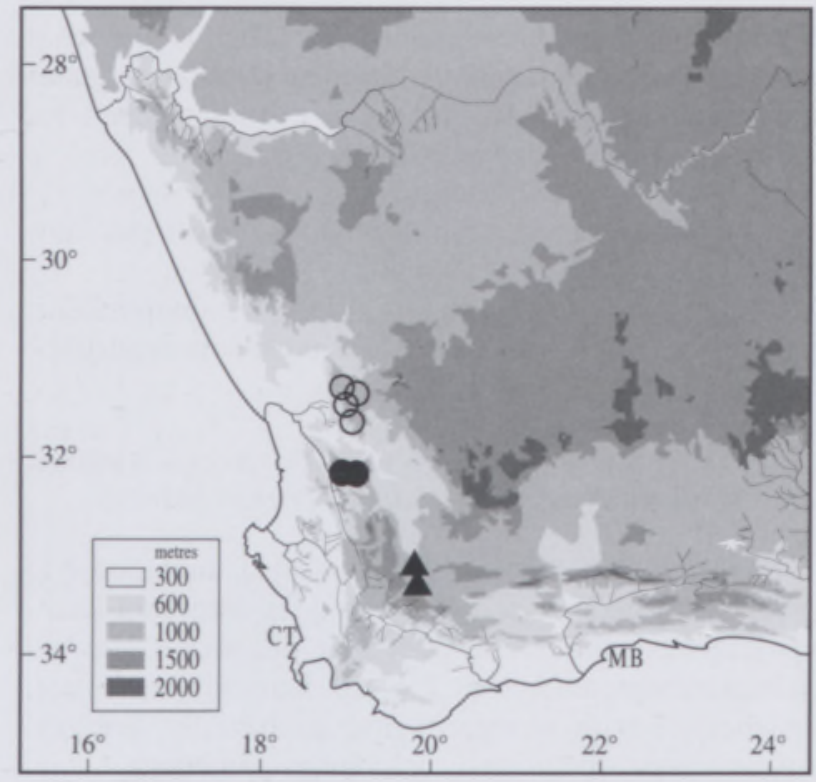

FIGURE 3.-Distribution of Cyanella alba subsp. alba, O; subsp. flavescens, $\bullet$; subsp. minor, $\mathbf{A}$

vidual flowers are borne on elongated pedicels up to 200 $\mathrm{mm}$ long, and because of the highly condensed inflorescence axis, appear to arise singly from among the leaves. The leaves in the remaining species are lanceolate to narrowly lanceolate and the inflorescence is distinctly racemose, with individual flowers borne on short pedicels. There is significant variation in flower colour within $C$. $a l b a$, with the tepals varying from white to yellow, or rarely pale pink. Scott (1991) referred to minor morphological differences between the colour forms and suggested that further investigation might provide a clearer picture of the 'distribution....and infraspecific variation' of the species. Examination of the species in the field and in the herbarium indicates that the geographical distribution of the species is strongly correlated with differences in flower colour and some other morphological traits.

Cyanella alba is restricted to mountain renosterveld, a sclerophyllous, evergreen shrubland dominated by the asteraceous shrub Elytropappus rhinocerotis (L.f.) Less., occupying fine-grained clay soils of the Bokkeveld Series that receive moderate amounts of winter rainfall, from 250 to $450 \mathrm{~mm}$ per year (Low \& Rebelo 1996). The species has a discontinuous distribution along the mountain ranges of the west coast of Western Cape, from Nieuwoudtville in the north to Karoo Poort, east of Ceres in the south, a distance of some $200 \mathrm{~km}$. Within this arc, the species occurs in three disjunct groups of populations (Figure 3). The northern populations, distributed along the Bokkeveld Escarpment, are characterized by their white or rarely pale pink flowers flushed with darker pink on the reverse of the tepals. The anthers are uniformly yellow and the upper five are either coherent or free from one another. The plants are often well grown, producing more than three and up to nine flowers on long pedicels, (80-)100-200 mm in length. Each pedicel bears a well-developed bracteole arising at a point between one third and three-quarters along its length.

A second group of populations occurs just south of the Bokkeveld, in the northern Cederberg Mountains around 
Clanwilliam and the Biedouw Valley. They are separated from the Bokkeveld populations by the arid expanse of the Doorn River Valley, which supports a succulent karoo vegetation in which $C$. alba does not grow. The Cederberg populations resemble the Bokkeveld populations in stature but are distinguished from them by their flower colour. In these plants the tepals (sometimes only the inner whorl but usually both whorls) are pale yellow rather than white, and the upper five anthers are invariably coherent and marked on their outer (upper) face with a prominent dark maroon or blackish blotch near the base. Like the Bokkeveld plants, the pedicels are bracteolate.

A third group of populations occurs well to the south at Karoopoort, in small patches of renosterveld that fringe the arid Tanqua River Basin. These plants are typically smaller in stature with fewer, up to three and often just one flower per plant, borne on pedicels that are mostly less than $100 \mathrm{~mm}$ long, rarely up to $150 \mathrm{~mm}$. The flowers are white or pale pink, flushed darker pink on the reverse, and the upper five anthers are coherent and uniformly yellow. Superficially the plants resemble small forms of the Bokkeveld genotype, and it could be argued that they represent nothing more than depauperate forms from marginal habitats at the edge of the distribution. However, closer examination reveals that the bracteoles on the pedicels have been completely suppressed and are thus lacking. In this respect the plants are unique in the genus.

The three disjunct groups of populations of Cyanella alba are thus morphologically distinct from one another. These morphological distinctions point to long-standing separation, sufficient to allow genetic drift, suggesting that the disjunctions are interpreted to be the result of isolation due to the intervening areas of aridity rather than the alternative hypothesis of recent fragmentation through farming activities also offered by Scott (1991). Since each of the groups of populations is geographically isolated from the other, and is morphologically distinguishable, it is appropriate to recognize them at the level of subspecies. The homogeneous nature of each of the groups of populations points to genetic continuity within each group, while the differences between them indicate significant levels of genetic discontinuity. This is highly significant in the context of the high levels of microgeographic speciation that characterize much of the Cape flora (Goldblatt \& Manning 2000).

Cyanella alba L.f: 201 (1781). Type: Sheet 430/4, Thunberg collection in herb. Linn. (LINN, lecto.; NBG, microfiche!).

\section{subsp. alba}

Plants (80-)100-200 mm high. Leaves linear, 1-3 mm wide. Pedicels bracteolate. Flowers 3-9, white to pale pink. Anthers uniformly yellow.

Distribution: Northern Cape, Bokkeveld Escarpment from just north of Nieuwoudtville southwards to Menzieskraal (Figure 3). The collection Stokoe SAM55591 from the Nardouwsberg north of Clanwilliam, while certainly this form, is doubtfully correctly localized. The Nardouwsberg is a sandstone range that provides no suitable habitats for the species and although it is well explored, the species has never been collected there again. There are other instances of mislabelling by Stokoe (Goldblatt \& Manning 2000: 507).

\section{Additional material examined}

NORTHERN CAPE.-3119 (Calvinia): $\mathrm{N}$ of Nieuwoudtville, Grasberg, (-AC), 16 September 1961, W.F. Barker 9457 (NBG); top of Van Rhyn's Pass, (-AC), 29 November 1974, W. Wisura 2991 (NBG); Van Rhyn's Pass, S side, (-AC), 4 October 1962, G.J. Lewis 6126 (NBG); Nieuwoudtville Reserve, (-AC), 8 September 1983, P.L. Perry \& D. Snijman 2351 (NBG); Nieuwoudtville Reserve, (-AC), 12 October 1983, P.L. Perry \& D. Snijman 2383 (NBG); Nieuwoudtville, (-AC), January 1931, J.W. Mathews NBG2270/30 (BOL); near Nieuwoudtville, (-AC), September 1941. T.P. Stokoe 8693 (BOL); 11 $\mathrm{km}$ from Nieuwoudtville in direction of Calvinia, Van Wyk's Farm, September 1930, (-AC), L. Bolus 19587 (BOL); $\pm 15 \mathrm{~km} \mathrm{~S}$ of Nieuwoudtville, Matjiesfontein, (-AC), 13 September 1976, M.F. Thompson 2902 (NBG); $15 \mathrm{~km}$ SSW of Nieuwoudtville, Oorlogskloof Nature Reserve, Farm Driefontein, (-CA), 10 October 1996, W.A.J. Pretorius 360 (NBG); Farm Lokenberg, (-CA), 4 September 1985, $D$. Snijman 905 (NBG); Lokenburg, (-CA), 29 August 1941, E. Esterhuysen 5751 (BOL); Menzieskraal, (-CA), 29 September 1933, Markotter s.n. (NBG).

\section{Doubtful locality}

WESTERN CAPE.-3118 (Vanryhnsdorp): Nardouw Pass, (-DD), September 1941, T.P. Stokoe SAM55591 (SAM).

\section{subsp. flavescens J.C.Manning, subsp. nov.}

A ceteris subspeciebus habitu 120-200 mm elato, foliis lineari-filiformibus et 1-2 mm latis, pedicellis bracteolatis, floribus $1-4$ et dilute flavis vel tepalis externis albis, antheris superis ad basim maculatis differt.

TYPE.-Western Cape, 3218 (Clanwilliam): Biedouwberg, (-AA), 26 August 1896, R. Schlechter 8686 (NBG, holo.!; BOL, PRE, iso.!).

Plants 120-200 mm high. Leaves linear-filiform, 1-2 mm wide. Pedicels bracteolate. Flowers $1-4$, pale yellow or outer tepals white. Anthers yellow, upper five maculate, marked with dark blotch near base.

Distribution: Western Cape, northern Cederberg, between Clanwilliam and Wuppertal, especially common in the Biedouw River Valley (Figure 3).

\section{Additional material examined}

WESTERN CAPE.-3218 (Clanwilliam): Clanwilliam, (-BB), 4 August 1896, R. Schlechter 8405 (BOL); Clanwilliam, (-BB), no date, C.L. Leipoldt 254 (SAM); Clanwilliam, (-BB), 30 August 1930 (cult.), E. Strassburger s.n. (NBG); $10 \mathrm{~km}$ S of Clanwilliam, (-BB), 12 September 1997. P. Goldblatt \& J. Manning 10741 (MO, NBG). 3219 (Wuppertal): Biedouwberg, (-AA), 3 September 1933, F.M. Leighton s.n. (BOL); Biedouw Hill, (-AA), 1984, G. Scott 2 (NBG); Biedouw Mountain. (-AA), 20 September 1937, G.J. Lewis s.n. (NBG); bottom of pass into Biedouw Valley, (-AA), 24 August 1967, M.F. Thompson 352 (NBG); bottom of hill to Biedouw Valley, (-AA), 9 August 1984, P.L. Perry 3145 (NBG); Welbedacht, (-AA), 20 September 1937, W.F. Barker 283 (NBG); Koudeberg near Wuppertal, (-AA), 4 October 1897. H. Bolus 9095 (NBG); Citadel Kop, (-AA), 7 September 1953, R.H. Compton 24237 (NBG): Wuppertal, (-AA), 18 August 1938, B. Martin NBG1794/37 (NBG); near Wuppertal, (-AA), 28 August 1951, B.E. Martin $81 /$ (NBG).

$$
\text { subsp. minor J.C.Manning, subsp. nov. }
$$

A ceteris subspeciebus habitu $80-150 \mathrm{~mm}$ elato, foliis filiformibus et $0.5-1.5 \mathrm{~mm}$ latis, pedicellis ebracteo- 
latis, floribus $1-3$ et albis vel dilute roseis, antheris uniformiter flavis differt.

TYPE.-Western Cape, 3319 (Worcester): Karoopoort, (-BA), 27 September 1944, W.F. Barker 3024 (NBG, holo.!).

Plants 80-150 mm high. Leaves filiform, 0.5-1.5 mm wide. Pedicels ebracteolate. Flowers $1-3$, white to pale pink with darker pink on reverse. Anthers uniformly yellow.

Distribution: Western Cape, east of Ceres at Karoopoort (Figure 3). Curiously, although Scott (1991: 46) did not cite any specimens corresponding to subsp. minor, she did provide dots indicating its distribution. The solitary, disjunct dot to the west of the main range of the subspecies is an error.

\section{Additional material examined}

WESTERN CAPE.-3319 (Worcester): Ceres, (-BA), October 1929, H. Neilson NBG1794/29 (BOL); Hottentots' Kloof, (-BA), 25 September 1945, Kirstenbosch Expedition NBG413/44 (NBG) Karoopoort, (-BA), 19 September 1938, M.R. Levyns 6236 (BOL); 10 miles N of Karoopoort, (-BA), 19 September 1954, H. Hall 949 (NBG).

\section{ACKNOWLEDGEMENTS}

Dr Peter Bruyns very kindly provided the Latin diagnoses.
REFERENCES

BRUMMITT, R.K., BANKS, H., JOHNSON, M.A.T., DOCHERTY, K.A., JONES, K., CHASE, M.W. \& RUDALL, P.J. 1998. Taxonomy of Cynastroideae (Tecophilaeaceae): a multidisciplinary approach. Kew Bulletin 53: 769-803.

CARTER, S. 1962. Revision of Walleria and Cyanastrum (Tecophilaeaeceae). Kew Bulletin 16: 185-195.

FOREST, F. \& MANNING, J.C. 2005. Systematics and biogeography of Tecophilaeaceae: insights from plastid DNA sequences. In preparation.

GOLDBLATT, P. \& MANNING, J.C. 2000. Cape plants. A conspectus of the Cape flora of South Africa. Strelitzia 9. National Botanical Institute, Cape Town \& Missouri Botanical Garden.

GUNN, M. \& CODD, L.E. 1981. Botanical exploration of southern Africa Balkema, Cape Town.

LINNAEUS, C. (fil.) 1782 (1781). Supplementum plantarum. Orphanotropheus, Brunswick.

LOW, A.B. \& REBELO, A.G. 1996. Vegetation of South Africa, Lesotho and Swaziland. Department of Environmental Affairs and Tourism, Pretoria.

MANNING, J.C., GOLDBLATT, P. \& SNIJMAN, D.A. 2002. The color encyclopedia of Cape bulbs. Timber Press, Oregon.

SCHINZ, H. 1902. Beitrage zur Kenntnis der Afrikanischen Flora. Haeomodoraceae. Bulletin de l'Herbier Boissier, sér. 2, 2: 943, 944.

SCOTT, G. 1991. A revision of Cyanella (Tecophilaeaceae) excluding $C$. amboensis. South African Journal of Botany 57: 34-54.

SIMPSON, M.G. \& RUDALL, P.J. 1998. Tecophilaeaceae. In K. Kubitzki, The families and genera of vascular plants: 429-436. Springer, Hamburg. 